\title{
Estimating leaf area of prata-type banana plants with lanceolate type leaves
}

\author{
Lucas Titonelli Ferreira Donato ${ }^{1}$, Sérgio Luiz Rodrigues Donato ${ }^{2}$, \\ Cleiton Fernando Barbosa Brito 3 , Varley Andrade Fonseca ${ }^{3}$, Carlos Nick Gomes ${ }^{4}$, \\ Vagner Alves Rodrigues Filho ${ }^{5}$
}

\begin{abstract}
Models for estimating leaf area of bananas found in the literature are not suitable for lanceolate type leaves occurring at the vegetative stage of ratoon suckers dependent of mother plant. The objective was to determine equations for estimating the leaf area of 'Prata-Anã' and 'BRS Platina' banana plants with lanceolate type leaves. 212 and 164 lanceolate type leaves having $10 \mathrm{~cm}$-wide lamina or less were collected from 'Prata-Anã' and 'BRS Platina' banana plants of 90 days of age or less, respectively. Width (W), length (L), width/length ratio (WLR), and scanner-measured leaf area $\left(\mathrm{LA}_{\text {scanner }}\right)$ were determined. Using the backward elimination procedure, simple and multiple linear regression equations were fitted to the relationship between leaf dimensions (W, L and WLR) and $\mathrm{LA}_{\text {scanner }}$. To evaluate how precise the equations are in predicting leaf area $\left(\mathrm{LA}_{\text {predicted }}\right)$, Pearson correlation coefficients were calculated between $\mathrm{LA}_{\text {predicted }}$ and $\mathrm{LA}_{\text {scanner. }}$ The models highly correlated with $\mathrm{LA}_{\text {scanner }}$ at $1 \%$ of

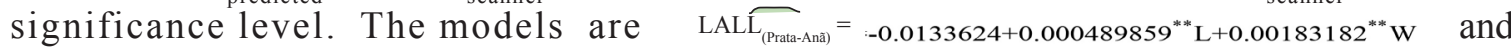
LALL $\widetilde{L_{\text {(Platina) }}}=0.00237026+0.00478116^{* * *} \mathrm{~W}-0.0968020^{* * *} \mathrm{WLR}$.
\end{abstract}

Index terms: Young bananas, multiple linear regression, narrow leaves

\section{Estimativa de área foliar em bananeiras tipo prata em estádio fenológico com folhas lanceoladas}

Corresponding author:

cleiton.ibce@hotmail.com

Received: February 20, 2020 Accepted: May 18, 2020

Copyright: All the contents of this journal, except where otherwise noted, is licensed under a Creative Commons Attribution License.

\section{(cc) $\mathrm{EY}_{\mathrm{Y}}$}

Resumo - Os modelos de estimativa de área foliar descritos na literatura são inapropriados para folhas tipo lanceoladas, na fase de crescimento vegetativo dependente do broto de sucessão, até os 90 dias de idade. Desta forma, objetivou-se ajustar equações para estimativa de área foliar em bananeiras 'PrataAnã' e 'BRS Platina' em plantas com folhas lanceoladas. Foram coletadas 212 folhas do tipo lanceoladas com até $10 \mathrm{~cm}$ de comprimento de limbo, de bananeiras 'Prata-Anã', e 164 de 'BRS Platina', com idade de até 90 dias. Foram mensuradas largura (L), comprimento (C), relação largura-comprimento (RLC) e área foliar ( $\left.\mathrm{AF}_{\text {escâner}}\right)$, determinada em escâner. Através do procedimento backward no SAEG, ajustaram-se equações de regressão linear múltipla, em função das variáveis L, C e RLC e AF escâner Para avaliar a qualidade da predição da área foliar calculada através das equações $\left(\mathrm{AF}_{\text {predita }}\right)$, ajustou-se uma correlação linear de Pearson entre a área $\mathrm{AF}_{\text {predita }}$ e $\mathrm{AF}_{\text {escâner }}$. Após os ajustes das equações de regressão linear múltipla, obtiveram-se modelos que demonstraram alto coeficiente de correlação com $\mathrm{AF}_{\text {escâner' }}$ a 1\% de significância. Os modelos ajustados para a determinação da área foliar de bananeiras jovens, com folhas lanceoladas, são: $\mathrm{AFFL}_{(\text {Prata-Anã) }}=-0,0133624+0,000489859 * * \mathrm{C}-0,00183182 * * \mathrm{~L} \mathrm{e}$ $\mathrm{AFFL}_{\text {(Platina) }} 0,00237026+0,004781 * * \mathrm{~L}-0,096802 * *$ RLC.

Termos para indexação: bananeira jovem, regressão linear múltipla, folhas estreitas.

\footnotetext{
${ }^{1}$ Agronomist - Trainee at Schroeder's Flowers, Green Bay, Wisconsin - EUA. E-mail: lucastitonelli97@gmail.com (ORCID: 0000-0002-2650-9089) ${ }^{2}$ Professor at the Instituto Federal de Educação, Ciência e Tecnologia Baiano, Guanambi-BA, Brazil. E-mail: sergio.donato@ifbaiano.edu.br ${ }^{\text {(ORCID: }}$ $0000-0002-7719-4662)$

${ }^{3}$ Doctoral student at Graduate Program in Plant Production in the Semiarid region, Universidade Estadual de Montes Claros - UNIMONTES, Janaúba-MG, Brazil. E-mail: cleiton.ibce@hotmail.com (ORCID: 0000-0001-9423-4980); varley.ibce@ig.com.br ${ }^{(O R C I D: 0000-0002-1562-2190)}$

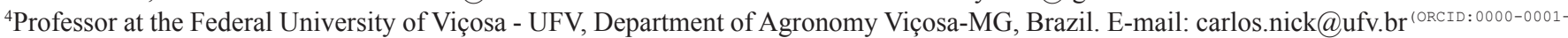
5990-255X)

${ }^{5}$ Doctoral student at Graduate Program - Agriculture Microbiology, Federal University of Viçosa - UFV, Viçosa- MG, Brazil. E-mail: vagner. rodrigues@ufv.br(ORCID:0000-0001-7702-7445)
} 


\section{Introduction}

Leaf area is a highly relevant component in agronomic and physiological studies. It provides information about plant metabolism and gives insight into ways of enhancing plant genetic resources. Methods for determining leaf area should be simple, time efficient, and precise (SOUZA et al., 2012). Numerous direct and indirect approaches have been developed to address leaf area determination (PEKSEN, 2007).

Direct methods are destructive. Measurements are taken, generally using a scanner, directly from leaves; thus, leaves must be detached from the plant, which is often impossible due to the limited number of plants composing the experimental unit. Indirect methods, however, are nondestructive and based on a known correlation between measured variables and leaf area, so the measurements used for calculations are taken without removing any structure from plants (SOUZA et al., 2012).

Recent studies have been carried out aimed at estimating the leaf area using linear dimensions measured on leaves of several crops (CARGNELUTTI FILHO et al., 2012; TOEBE et al., 2012; MORGADO et al., 2013; HINNAH et al., 2014). However, studies on determining the leaf area of bananas are not recent (SIMMONDS, 1973; ALVES et al., 2001; KUMAR et al., 2002; TURNER, 2003; ZUCOLOTO et al., 2008).

Total leaf area of banana plants can be estimated using the following measurements and constants: a) Simmonds (1973) - N, total number of leaves; L, leaf length; $\mathrm{W}$, leaf width; and 0.80 , a proportionality factor; b) Alves et al. (2001) -as the previous method, butthe factor is replaced with 0.5789 ; c) Kumar et al. (2002) $-\mathrm{N}, \mathrm{L}, \mathrm{W}$, the proportionality factor $(0.80)$, and a 'new factor' of 0.662 ; d) Integral method, Turner (2003) $-\mathrm{A}_{\mathrm{i} \text {, }}$ ${ }_{N}$, integration of the leaf areas between leaf $i$, the oldest leaf at the time of measurement, and leaf $N$, the youngest leaf; $A_{n}$, the area of the youngest leaf; $N$, the number of green leaves on the plant; $A_{p}$, the area of the first leaf in the plateau phase; $\mathrm{N}_{\mathrm{e}}$, the number of leaves included in the exponential phase; and $\mathrm{N}_{\mathrm{p}}$, the number of leaves in the plateau phase; e) Zucoloto et al. (2008) -0.5187; L; $\mathrm{W} ; \mathrm{N}$; and 9603.5 , which was specifically developed for 'Prata-Anã' banana plants.

A change in leaf lamina shape occurs as the banana plant develops. It defines the transition from an early, slowgrowing vegetative stage, to a fast-growing vegetative stage. Also, the change in the leaf lamina shape signals the end of the hormonal inhibition of suckers by the mother plant (SOTO BALLESTERO, 2008; DONATO et al., 2015).

Sword suckers are large suckers with lanceolate type leaves (lower width to length ratio). When sword suckers are around 90 days old, the leaf lamina, which should measure by then approximately $10 \mathrm{~cm}$ wide (leaf $\mathrm{F}_{10}$ ), becomes wider, which increases the width/length ratio. The ratio keeps increasing until the leaf lamina assumes the varietal standard form at flower differentiation, which occurs around 180 days. For this reason, estimating the leaf area of bananas is reasonable only when using adult banana plants because equations found in the literature were developed based on measurements taken from leaves of fully developed plants.

A problem arises in determining the leaf area of banana plants with lanceolate type leaves or sword suckers (SOTO BALLESTERO, 2008). This poses a limitation, for example, on studies assessing changes in specific leaf area from sucker to adult stage. Therefore, the leaf area of sword suckers is inadequately estimated because their width to length ratio is lower than that of older leaves having the varietal leaf shape.

As equations for estimating the leaf area of sword suckers have not been developed and non-destructive methods are preferred over destructive ones, the objective was to determine models for estimating leaf area of Pratatype bananas with lanceolate type leaves.

\section{Material and methods}

Models were determined for estimating the leaf area of suckers with lanceolate type leaves using data from two experimental Prata-type banana plantations in the first ratoon crop cycle.

The experimental areas were located at the Instituto Federal Baiano - campus Guanambi, Bahia, Brazil (14 ${ }^{\circ} 13^{\prime} \mathrm{S}, 42^{\circ} 46^{\prime} \mathrm{W}$, and altitude of $545 \mathrm{~m}$ ). The soil was a red-yellow latosol. The climate is semi-arid characterized by mean annual rainfall below $800 \mathrm{~mm}$, Thornthwaite's aridity index lower than or equal to 0.5 (calculated by the water balance), and drought risk or percentage of water deficit higher than or equal to $60 \%$ for a given day of the year (BRASIL, 2017). Mean annual temperature and precipitation are $25.9^{\circ} \mathrm{C}$ and $670.1 \mathrm{~mm}$, respectively.

'PrataAnã' (AAB) and 'BRS Platina' (AAAB) bananas were cultivated on experimental area 1 and 2, respectively, both irrigated with micro-sprinklers. In June 2018, 212 leaves were collected from area 1 and 164 leaves from area 2. The leaves were collected from up to 90-d-old sword suckers. Leaf width ranged from 1 to $10 \mathrm{~cm}$.

Leaf width (W) and length (L) were measured with a tape measure. Then, the width/length ratio (WLR) was calculated. Leaf width was measured at the widest part of the leaf while leaf length was taken as the length of the midrib. The leaf area $\left(\mathrm{LA}_{\text {scanner }}\right)$ was measured using a scanner AM300 - portable leaf area meter (ADC BioScientific Limited, UK).

The data were tested for normality (Liliefors). Descriptive statistics were calculated: mean, standard deviation, coefficient of variation, andthe highestand lowest value recorded. Pearson correlation coefficients 
were determined between $\mathrm{LA}_{\text {scanner }}$ and leaf dimensions (W, L, and WLR).

To determine simple and multiple linear regression equations relating $\mathrm{LA}_{\text {scanner }}$ and leaf dimensions (W, L, and WLR), the procedure 'backward elimination' on SAEG was used (RIBEIRO, JÚNIOR MELO, 2008).

Backward elimination procedure consists of fitting a multiple linear regression model containing all independent variables. Then, an independent variable with the lowest $t$ value is deleted from the equation one at a time. The new equation is recalculated while considering the significance of the F-test from the analysis of variance of the equation. The selection of models after deletion of an independent variable took into consideration the following: the significance of beta coefficients calculated by the $t$ test, the coefficient of determination, the least difference between the coefficient of determination $\left(\mathrm{R}^{2}\right)$ and the adjusted coefficient of determination $\left(\mathrm{R}^{2}{ }_{\text {adj }}\right)$, how well the model fits the observed data, and the simplicity of the model when $\mathrm{R}^{2}$ and $\mathrm{R}^{2}$ adj values were similar.

The model containing $\mathrm{k}$ independent variables can be determined with the following multiple linear equation: $Y i=\beta 0+\beta 1 X 1 \mathrm{i}+\beta 2 X 2 \mathrm{i}+\ldots+\beta \mathrm{k} X \mathrm{ki}+\varepsilon \mathrm{i}$
Where: $Y i$ is the response variable or dependent variable determined as a function of independent variables, $\mathrm{W}, \mathrm{L}$, and WLR $(\mathrm{Xi} ; \ldots ; \mathrm{Xk}) ; \varepsilon \mathrm{i}$ is the error associated with the nth observation; $\beta 0$ is a constant of the model, $\beta 1, \ldots, \beta \mathrm{k}$ are coefficients of the model.

Furthermore, the Pearson correlation coefficient was calculated between the predicted leaf area $\left(\mathrm{LA}_{\text {predicted }}\right)$ and the measured leaf area $\left(\mathrm{LA}_{\text {scanner }}\right)$ to determine how well the selected model predicts the leaf area of 'PrataAnã' and 'BRS Platina' bananas.

\section{Results and discussion}

\section{Prata-Anã cultivar}

Table 1 contains measures of central tendency (mean) and variability (standard deviation and coefficient of variation), as well as the highest and lowest values of $\mathrm{W}, \mathrm{L}, \mathrm{WLR}$, and $\mathrm{LA}_{\text {scanner }}$ collected from lanceolate type leaves of 'Prata-Anã' bananas. Leaf width ranged from 1.60 to $10.10 \mathrm{~cm}$, leaf length from 20.10 to $57.60 \mathrm{~cm}$, WLR from 0.05 to $0.33 \mathrm{~cm} / \mathrm{cm}$, and $\mathrm{LA}_{\text {scanner }}$ from 0.003189 to $0.031721 \mathrm{~m}^{2}$.

Table 1. Descriptive statistics of length, width, width/length ratio, and leaf area of sword suckers of 'Prata-Anã' and 'BRS Platina' bananas

\begin{tabular}{|c|c|c|c|c|c|}
\hline \multirow{2}{*}{ Descriptive statistics } & Length $(\mathrm{cm})$ & Width $(\mathrm{cm})$ & WLR $(\mathrm{cm} / \mathrm{cm})$ & $\mathrm{LA}_{\text {scanner }}\left(\mathrm{m}^{2}\right)$ & $\mathrm{LA}_{\text {predicted }}\left(\mathrm{m}^{2}\right)$ \\
\hline & & & \multicolumn{3}{|c|}{ 'Prata-Anã' } \\
\hline Mean* & 32.93 & 5.20 & 0.1555 & 0.012301 & 0.012301 \\
\hline Standard deviation* & 7.21 & 2.20 & 0.0527 & 0.007109 & 0.006978 \\
\hline CV $(\%)^{*}$ & 21.89 & 42.20 & 33.92 & 57.79 & 56.73 \\
\hline Highest* & 57.60 & 10.10 & 0.3373 & 0.031721 & 0.029508 \\
\hline Lowest* & 20.10 & 1.60 & 0.0593 & 0.003189 & 0.001859 \\
\hline \multicolumn{6}{|l|}{ 'BRS Platina' } \\
\hline Mean $^{*}$ & 35.23 & 6.18 & 0.1725 & 0.015251 & 0.015209 \\
\hline Standard deviation* & 5.37 & 1.98 & 0.0395 & 0.006302 & 0.006139 \\
\hline $\mathrm{CV}(\%)^{*}$ & 15.25 & 32.01 & 22.92 & 41.32 & 40.36 \\
\hline Highest $^{*}$ & 47.90 & 10.00 & 0.2659 & 0.028873 & 0.027928 \\
\hline Lowest ${ }^{*}$ & 24.00 & 2.70 & 0.0976 & 0.005332 & 0.005161 \\
\hline
\end{tabular}

Note: ${ }^{*} \mathrm{n}=212 ; \mathrm{WLR}$, width/length ratio; $\mathrm{LF}_{\text {scanner }}$, leaf area measured with scanner AM300; $\mathrm{LF}_{\text {predicted }}$, leaf area predicted by models (Figure 1).

The variability within $\mathrm{W}$ values was twice as large as that within $L$ values, with coefficient of variation $(\mathrm{CV})$ of $42.20 \%$ against $21.89 \%$, respectively. This variability is high and reflects the instability of leaf dimensions within lanceolate type leaves. For comparison, the CV of width and length of leaves collected from fully developed 'PrataAnã' banana plants was $5.94 \%$ and $5.45 \%$, respectively (ARANTES et al., 2017). This shows the low variability of these characteristics when the leaf is already in its varietal standard form.
Zucoloto et al. (2008), working with adult 'PrataAnã' banana plants, reported that the mean, the highest value, and the lowest value were $153.5 \mathrm{~cm}, 171 \mathrm{~cm}$, and $118 \mathrm{~cm}$ for $\mathrm{L} ; 65.55 \mathrm{~cm}, 75 \mathrm{~cm}$, and $50 \mathrm{~cm}$ for $\mathrm{W}$; and $0.42 \mathrm{~cm} / \mathrm{cm}, 0.43 \mathrm{~cm} / \mathrm{cm}$, and $0.42 \mathrm{~cm} / \mathrm{cm}$ for WLR, respectively. Arantes et al. (2017) found mean values of $197.06 \mathrm{~cm}$ and $223.07 \mathrm{~cm}$ for L, $75.63 \mathrm{~cm}$ and 79.60 $\mathrm{cm}$ for $\mathrm{W}$, and $0.38 \mathrm{~cm} / \mathrm{cm}$ and $0.35 \mathrm{~cm} / \mathrm{cm}$ for WLR of adult banana plants in the first and second crop cycle, respectively. 
In comparing the variation in WLR of lanceolate type leaves, which ranged from 0.0593 to $0.3373 \mathrm{~cm} / \mathrm{cm}$ (Table 1), to WLR of leaves ranging from $0.42-0.43$ $\mathrm{cm} / \mathrm{cm}$ and collected from adult plants (ZUCOLOTO et al., 2008), the difference between leaf lamina shapes is evident. Sword suckers' leaves retain a lower WLR until they are 90 days old, at which the vegetative stage dependent of mohter plant ends as the leaf lamina reaches approximately $10 \mathrm{~cm}$ wide, called $\mathrm{F}_{10}$ leaves. The width to length ratio increases until it stabilizes at flower differentiation, which takes place when plants are approximately 180 days old. The presence of $F_{10}$ leaves signals the end of the hormonal inhibition of suckers by mother plants (SOTO BALLESTERO, 2008; DONATO et al., 2015).
Values of $\mathrm{LA}_{\text {scanner }}$ correlated directly and significantly with $\mathrm{W}, \mathrm{L}$, and WLR (Table 2). The correlations suggest that it is possible to use these variables to fit models for predicting leaf area of bananas with lanceolate type leaves. These results are relevant since the models found in the literature (SIMMONDS, 1973; ALVES et al., 2001; KUMAR et al., 2002; TURNER, 2003; ZUCOLOTO et al., 2008) were determined for leaves in their adult form and are therefore unsuitable for estimating the leaf lamina area of younger leaves with lower width/length ratio.

Table 2. Correlations of leaf area of 'Prata-Anã' and 'BRS Platina' banana suckers with lanceolate type leaves measured with an AM300 scanner - portable leaf area meter (ADC BioScientific Limited, UK) with length, width, and width/ length ratio

\begin{tabular}{lccccc}
\hline \multirow{2}{*}{ Variable } & \multirow{2}{*}{ Variable } & \multicolumn{2}{c}{ 'Prata-Anã' } & \multicolumn{2}{c}{ 'BRS Platina' } \\
\cline { 3 - 6 } & & Correlation coefficient (r) & Significance & Correlation coefficient (r) Significance \\
\hline LA $_{\text {scanner }}$ & Length & 0.896 & $* *$ & 0.893 & $* *$ \\
LA $_{\text {scanner }}$ & Width & 0.916 & $* *$ & 0.952 & $* *$ \\
LA $_{\text {scanner }}$ & WLR & 0.571 & $* *$ & 0.775 & $* *$ \\
\hline
\end{tabular}

Note: ${ }^{n} \mathrm{n}=212$; WLR, width/length ratio. ${ }^{* *}$ significant correlation at $1 \%$.

Models for estimating leaf area in 'Prata-Anã' sword suckers were fitted to the relationship between $\mathrm{LA}_{\text {scanner }}$ and independent variables (W, L, and WLR) using the backward elimination procedure on SAEG (RIBEIRO, JÚNIOR; MELO, 2008). The models have coefficients of determination with values close to one another, 0.968, 0.966, and 0.963, when using W, L, and WLR; W and WLR; and W and L, respectively (Table 3). Conversely, coefficients of determination are lower when either $\mathrm{W}$ or $\mathrm{L}$ is used as the sole independent variable in simple linear regression models, with values of 0.839 and 0.802 , respectively.

Table 3. Simple and multiple linear regression equations relating scanner-measured leaf area $\left(\mathrm{LA}_{\text {scanner }}\right)$ to independent variables, length (L), width (W), and width/length ratio (WLR), of 'Prata-Anã' and 'BRS Platina' banana plants with lanceolate type leaves

\begin{tabular}{|c|c|c|c|}
\hline \multirow{2}{*}{$\begin{array}{l}\text { Independent } \\
\text { variables }\end{array}$} & Equation for estimating leaf area & $\mathrm{R}^{2}$ & $\mathrm{R}_{\text {adj }}^{2}$ \\
\hline & \multicolumn{3}{|l|}{ 'Prata-Anã' } \\
\hline $\begin{array}{l}\text { L, W and } \\
\text { WLR }\end{array}$ & $\widehat{\left.\operatorname{LALL}_{(\operatorname{Prata}}-\mathrm{Ana}\right)}=-0.004502+0.0001985^{* *} \mathrm{~L}+0.003603^{* * *} \mathrm{~W}-0.05458^{* *} \mathrm{WLR}$ & 0.968 & 0.968 \\
\hline W e WLR & $\operatorname{LALL}_{(\text {Prata-Anã) }}=0.001331+0.004729^{* * *} \mathrm{~W}-0.08775^{* *} \mathrm{WLR}$ & 0.966 & 0.966 \\
\hline L e W & $\left.\operatorname{LALL}_{(\operatorname{Prata}}-\mathrm{Ana}^{2}\right)=-0.0133624+0.000489859^{* * *} \mathrm{~L}+0.00183182^{* *} \mathrm{~W}$ & 0.963 & 0.963 \\
\hline $\mathrm{W}$ & $\operatorname{LALL}_{(\text {Prata }- \text { Anã) }}=-0.003135+0.002966^{* *} \mathrm{~W}$ & 0.839 & 0.838 \\
\hline $\mathrm{L}$ & 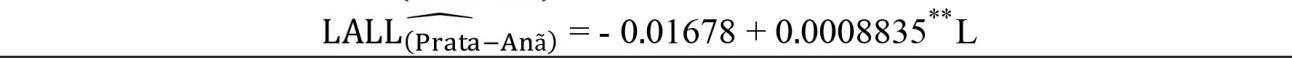 & 0.802 & 0.801 \\
\hline \multicolumn{4}{|c|}{ 'BRS Platina' } \\
\hline $\begin{array}{l}\text { L, W and } \\
\text { WLR }\end{array}$ & $\mathrm{LALC}_{\widehat{\mathrm{P}_{\text {(latına }}}}=0.001307+0.00003112^{\mathrm{ns}} \mathrm{L}+0.004598^{* *} \mathrm{~W}-0.09046^{* *} \mathrm{WLR}$ & 0.967 & 0.966 \\
\hline W and WLR & $\mathrm{LAL}_{\text {(Platina) }}=0.00237026+0.00478116^{* *} \mathrm{~W}-0.0968020^{* *} \mathrm{WLR}$ & 0.967 & 0.966 \\
\hline W & LAL $\widehat{L_{(\text {Platına })}}=-0.003362+0.003006^{* *} \mathrm{~W}$ & 0.907 & 0.906 \\
\hline $\mathrm{L}$ & $\mathrm{LAL}_{\mathrm{L}_{\text {(Platına })}}=-0.02133+0.001037^{* *} \mathrm{~L}$ & 0.797 & 0.796 \\
\hline
\end{tabular}

** significant at $1 \%$ by $\mathrm{t}$ test; $\mathrm{R}^{2}$, coefficient of determination; $\mathrm{R}_{\text {adj }}^{2}$, adjusted coefficient of determination 
The following equation for estimating the leaf area of 'Prata-Anã' banana with lanceolate type leaves was selected based on how well the model fits the phenomenon, how smaller the difference between $\mathrm{R}^{2}$ and $\mathrm{R}^{2}$ adj is, and how easy to use the model is in case of similarity between $\mathrm{R}^{2}$ and $\mathrm{R}_{\text {adj }}^{2}$ :

$\mathrm{LALC}_{(\text {Prata-Anã) }}=: 0.0133624+0.000489859^{* *} \mathrm{~L}+0.00183182^{* *} \mathrm{~W}$.
To evaluate how precise the selected equation is in predicting the leaf area of 'Prata-Anã' banana plants with lanceolate type leaves, the correlation between predicted leaf area and scanner-measured leaf area was measured by the Pearson correlation coefficient (r) (Figure 1A). The equation describing the relationship between predicted and actual values exhibited high precision with $\mathrm{R}^{2}$ of 0.963 , $\mathrm{R}_{\text {adj }}^{2}$ of 0.963 , and $\mathrm{r}$ of 0.981 .
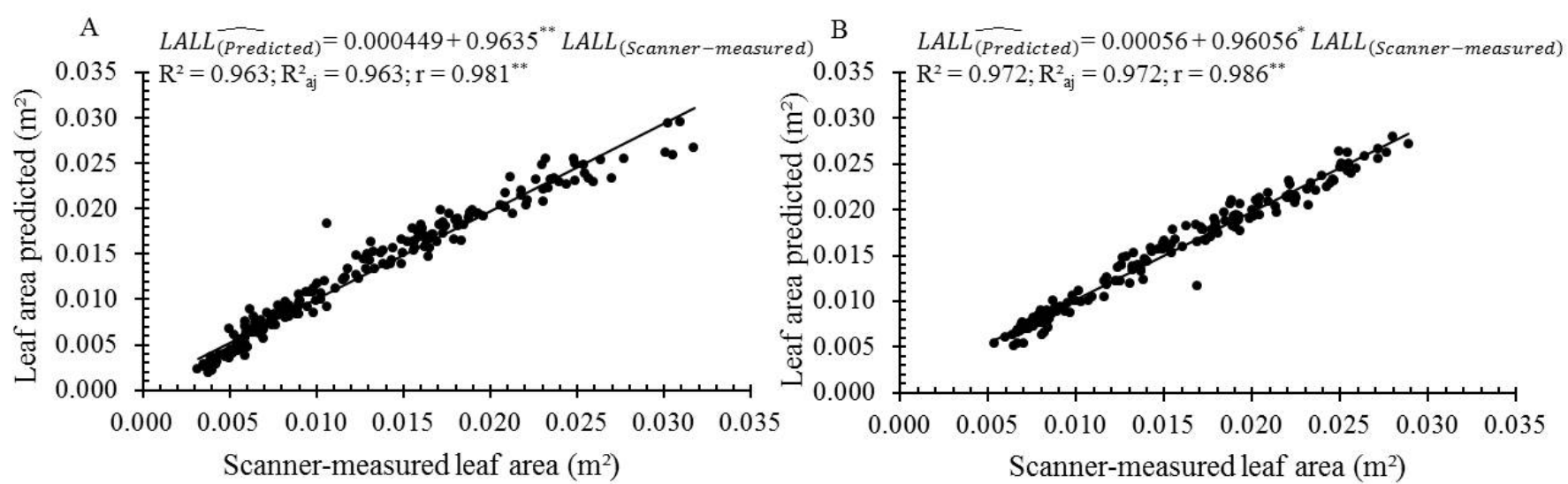

Figure 1. Precision of equations describing the relationship between the leaf area predicted by the models, $\mathrm{LALL}_{(\text {(Prata-Anã) }}-0.0133624+0.000489859^{* * *} \mathrm{~L}+0.00183182^{* *} \mathrm{~W}$ for 'Prata-Anã' banana $(\mathrm{A})$ and $\mathrm{LAL} \widetilde{\mathrm{L}_{\text {(Platina) }}}=0.002370+$ $0.004781^{* *} \mathrm{~W}-0.096802 * * \mathrm{WLR}$ for 'BRS Platina' banana (B), and the feaf area measured on a scanner.

LALL: leaf area of lanceolate type leaves; L, leaf length; W, leaf width; ** significant at $1 \%$ by $\mathrm{t}$ test; $\mathrm{R}^{2}$, coefficient of determination; $\mathrm{R}_{\text {adj' }}^{2}$ adjusted $\mathrm{R}^{2}$; r, correlation coefficient

\section{BRS Platina Cultivar}

Table 1 shows descriptive statistics including measures of position (mean) and dispersion (standard deviation and coefficient of variation), the highest and lowest values of $\mathrm{L}, \mathrm{W}, \mathrm{WLR}$, and $\mathrm{LA}_{\text {scanner }}$ values measured on lanceolate type leaves of 'BRS Platina' bananas. Leaf width ranged from 2.70 to $10.00 \mathrm{~cm}$, leaf length from 24.00 to $47.90 \mathrm{~cm}$, WLR from 0.09 to $0.26 \mathrm{~cm} / \mathrm{cm}$, and $\mathrm{LA}_{\text {scanner }}$ from 0.005332 to $0.028873 \mathrm{~m}^{2}$. Results are similar to those of 'Prata-Anã' bananas. The variability of $\mathrm{W}$ was twice as high as that of $\mathrm{L}$, with a coefficient of variation (CV) of $32.04 \%$ against $15.25 \%$, respectively. However, the variability was lower than that of 'Prata-Anã' banana. This might be due to the higher uniformity of 'BRS Platina', which is a hybrid of 'Prata-Anã'.

In any case, the variability of $\mathrm{L}$ and $\mathrm{W}$ values is high and shows how unstable leaf dimensions of lanceolate type leaves are. For comparisons, the CVs of $\mathrm{W}$ and $\mathrm{L}$ of adult leaves of 'BRS Platina' were 5.94\% and 5.45\%, respectively (ARANTES et al., 2017). Likewise, Marques et al. (2011) reported CVs of $6.57 \%, 4.27 \%$, and $6.33 \%$ for $\mathrm{L}$ and $\mathrm{CVs}$ of $4.50 \%, 5.04 \%$, and $3.91 \%$ for $\mathrm{W}$, in the first, second, and third crop cycle, respectively. These results show that the variability of adult leaves is much lower than younger leaves.
Arantes et al. (2017), working with 'BRS Platina' banana plants over two crop cycles, reported mean values of $206.31 \mathrm{~cm}$ and $224.30 \mathrm{~cm}$ for $\mathrm{L}, 73.75 \mathrm{~cm}$ and 70.70 $\mathrm{cm}$ for $\mathrm{W}$, and $0.35 \mathrm{~cm} / \mathrm{cm}$ and $0.31 \mathrm{~cm} / \mathrm{cm}$ for WLR, in the first and second crop cycle, respectively. Marques et al (2011) observed mean L values of $165.40 \mathrm{~cm}, 222.67$ $\mathrm{cm}$, and $240.69 \mathrm{~cm}$, mean $\mathrm{W}$ values of $60.75 \mathrm{~cm}, 90.40$ $\mathrm{cm}$, and $105.76 \mathrm{~cm}$, and mean WLR values of $0.36 \mathrm{~cm} /$ $\mathrm{cm}, 0.40 \mathrm{~cm} / \mathrm{cm}$, and $0.43 \mathrm{~cm} / \mathrm{cm}$ in the first, second and third crop cycles, respectively.

The difference in leaf lamina shape is evident when comparing the variation in WLR of lanceolate type leaves $(0.09$ to $0.26 \mathrm{~cm} / \mathrm{cm})$ (Table 1) with that in WLR of adult leaves $(0.40$ to $0.43 \mathrm{~cm} / \mathrm{cm}$ ) (MARQUES et al., 2011). Sword suckers' leaves retain a lower WLR until they are 90 days old, at which the vegetative stage depend of mother plant ends as the leaf lamina reaches approximately 10 $\mathrm{cm}$ wide, called $\mathrm{F}_{10}$ leaves. The WLR of leaves increases until it stabilizes at flower differentiation, which takes place when plants are approximately 180 days old. The presence of $\mathrm{F}_{10}$ leaves signals the start of the independence of a sucker from its mother plant (SOTO BALLESTERO, 2008; DONATO et al., 2015). 
Values of $\mathrm{LA}_{\text {scanner }}$ correlated directly and significantly with W, L, and WLR (Table 2). Similarly to what occurred with 'Prata-Anã' bananas, the highest correlation was between LA and W. The correlations, however, were overall higher in 'BRS Platina' than those for 'Prata-Anã'. The high and significant correlations suggest that it is possible to use these variables in fitting models for predicting the leaf area of lanceolate type leaves on banana plants.

Models for estimating leaf area of 'BRS Platina' with lanceolate type leaves were fitted to the relationship between $\mathrm{LA}_{\text {scanner }}$ and the independent variables (W, L, and WLR). The models have the coefficient of determination of 0.967 when using either W, L and WLR or W and WLR (Table 3). However, the coefficient is not significant when using $\mathrm{L}$. When using only $\mathrm{W}$ as independent variable, the precision is also high $\left(\mathrm{R}^{2}=0.906\right)$, but it decreases when using only $\mathrm{L}\left(\mathrm{R}^{2}=0.797\right)$.

Therefore, the following multiple linear regression equation was selected for estimating leaf area of 'BRS Platina' bananas having lanceolate type leaves:

$\mathrm{LALL}_{(\text {Platina) }}=0.00237026+0.00478116^{* \pi} \mathrm{W}-0.0968020^{* \pi} \mathrm{WLR}$.

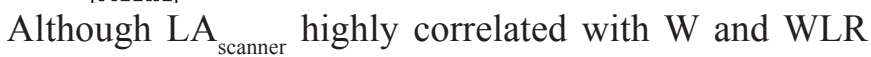
(Table 2), one can also use the simple linear regression equation: $\operatorname{LALL}_{\text {(Platina) }}=-0.003362+0.003006^{* *} \mathrm{~W}$, which uses only $\mathrm{W}$ as an entry variable.

To evaluate how precise the selected equation is in predicting the LA of 'BRS Platina' banana plants with lanceolate type leaves, the correlation between predicted leaf area and scanner-measured leaf area was measured by the Pearson correlation coefficient (r) (Figure 1B). The equation describing the relationship between predicted and scanner-measured values exhibited high precision with $\mathrm{R}^{2}$ of $0.972, \mathrm{R}_{\text {adj }}^{2}$ of 0.972 , and $\mathrm{r}$ of 0.986 .

The findings are important. By simply measuring leaf length and width in the field, leaf area estimates can be related to the banana's phenological cycle that includes an early vegetative cycle, thereby improving crop practices including irrigation and fertilizer management.

\section{Conclusions}

Width, length, and width/length ratio of lanceolate type leaves in 'Prata-Anã' and 'BRS Platina' banana plants correlated significantly with leaf area, with the highest correlation for 'BRS Platina'.

The models for determining leaf area of banana suckers with lanceolate type leaves are:

$\mathrm{LALL}_{\left(\mathrm{Prata}_{\text {anã) }}\right.}=-0.0133624+0.000489859^{* * *} \mathrm{~L}+0.00183182^{* * *} \mathrm{~W} ; \mathrm{R}^{2}=0.963$ and $\mathrm{R}_{\text {adj }}^{2}=0.963$;

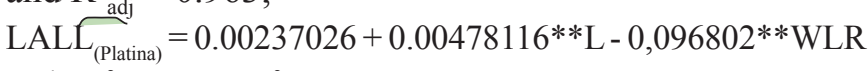
and $; \mathrm{R}^{2}=0.967 ; \mathrm{R}_{\text {adj }}^{2}=0.966$.

\section{References}

ALVES, A.A.C; SILVA, J.F.S; COELHO E.F. Estimation of banana leaf area by simple and non-destructive methods. In: CONGRESSO BRASILEIRO DE FISIOLOGIA VEGETAL ILHÉUS, 2001, Ilhéus. Anais [...]. Ilhéus: Sociedade Brasileira de Fisiologia Vegetal, 2001, v.1. CD-ROM.

ARANTES, A.M.; DONATO, SÉRGIO LUIZ RODRIGUES.; SILVA, T.S.; RODRIGUES FILHO, V.A.; AMORIM.; E.P. Agronomic evaluation of banana plants in three production cycles in southwestern state of Bahia. Revista Brasileira de Fruticultura, Jaboticabal, v.39, n.1, p.01-12, 2017.

BRASIL. Ministério da Integração Nacional.Relatório final, grupo de trabalho para delimitação do semiárido. Brasília, 2017.345p. Disponível em: http://www.sudene. gov.br/conselhodeliberativo/regimento-e-documentos/ resolucoes/103-a-109>. Acesso em: 10 de julho de 2018.

CARGNELUTTI FILHO, A.; TOEBE, M.; BURIN, C.; FICK A.L.NEU, I.M.M.; FACCO, G. Estimação da área foliar de mucuna cinza por meio de método não destrutivo. Ciência Rural, Santa Maria, v.42, n.2, p.238-242, 2012.

DONATO, S.L.R.; ARANTES, A.de M.; MARQUES, P.R.R.; RODRIGUES, M.G.V. Considerações ecofisiológicas e estratégias de manejo da bananeira. Informe Agropecuário, Belo Horizonte, v.36, n.288, p.13-26, 2015.

HINNAH, F.D.; HELDWEIN, A.B.; MALDANER, I.C.; LOOSE, L.H.; LUCAS, D.D.P.; BORTOLUZZI, M.P. Estimativa da área foliar da berinjela em função das dimensões foliares. Bragantia, Campinas, v.73, n.3, p.213-218, 2014.

KUMAR, N.V.; KRISHNAMOORTHY, L.; NALINA, K.; SOORIANATHA, S.L. A new factor for estimating total leaf area in banana. Infomusa, San José, v.11, n.2, p.42-43, 2002.

MARQUES, P.R.R.; DONATO, S.L.R.; PEREIRA, M.C.T.; COELHO, E.F.; ARANTES, A.de M. Características agronômicas de bananeiras tipo Prata sob diferentes sistemas de irrigação. Pesquisa Agropecuária Brasileira, Brasília, v.46, n.8, p.852-859, 2011. 
MORGADO, M.A.D.O.; BRUCKNER, C.H.; ROSADO, L.D.S.; ASSUNÇÃO, W.; SANTOS, C.E.M.dos. Estimação da área foliar por método não destrutivo, utilizando medidas lineares das folhas de espécies de Passiflora. Revista Ceres, Viçosa, v.60, n.5, p.662$667,2013$.

PEKSEN, E. Non-destructive leaf area estimation model for faba bean (Vicia faba L.). Scientia Horticulturae, Amsterdam, v.113, n.4, p.322- 328, 2007.

RIBEIRO JÚNIOR, J.I; MELO, A.L.P. Guia prático para utilização do SAEG. Viçosa: Editora Independente, 2008. 287p.

SIMMONDS, N.W. Los plátanos. Barcelona: Blume, 1973.539 p.

SOTO BALlestero, M. Bananos: tecnicas de produccion, poscosecha y comercializacion. Guacimo: EARTH, 2008. 1 CD-ROM.
SOUZA, M.S.; ALVES, S.S.V.; DOMBROSKI, J.L.D.; FREITAS, J.D.B.de.; AROUCHA, E.M.M. Comparação de métodos de mensuração de área foliar para a cultura da melancia. Pesquisa Agropecuária Tropical, Goiânia, v.42, n.2, p.241-245, 2012.

TOEBE, M.; CARGNELUTTI, A.F.; BURIN, C.; FICK A.L.NEU, I.M.M.; CASAROTTO, G.; ALVES, B.M. Modelos para a estimação da área foliar de feijão de porco por dimensões foliares. Bragantia, Campinas, v.71, n.1, p.37-41, 2012.

TURNER, D.W. An integral method for estimating total leaf area in bananas. Infomusa, San José, v.12, n.2, p.1517, 2003.

ZUCOLOTO, M; LIMA, J.S.S; COELHO, R.I. Modelo matemático para estimativa da área foliar total de bananeira Prata-Anã. Revista Brasileira de Fruticultura, Jaboticabal, v.30, n.4, p.1152-1154, 2008. 